\title{
El Niño-Southern Oscillation effects on peanut yield and nitrogen leaching
}

\author{
T. Mavromatis, S. S. Jagtap*, J. W. Jones \\ Department of Agricultural and Biological Engineering, University of Florida, Gainesville, Florida 32611, USA
}

\begin{abstract}
Peanut growers in north Florida asked for help in managing the crop to increase yield and reduce yield variability, using information on the pattern of large-scale climate. The objectives of this study were to explore at 4 locations in the peanut belt of Florida and southern Georgia the potential for improving peanut crop performance by altering crop management according to the phase of the El Niño-Southern Oscillation (ENSO). The CROPGRO-Peanut model was used to simulate peanut yield responses to climate and management. The effects of planting date and irrigation management options on the mean and variability of simulated crop yield and nitrogen leaching in different ENSO phases were estimated. This case study showed potential for enhancing peanut yields (1 to $8 \%$ ) and reducing yield variability (2 to $12 \%$ ) by tailoring planting dates to expected ENSO conditions, while at the same time reducing potential environmental damages from nitrogen leaching by 1 to $11 \%$. Locations which appeared to have no ENSO linkages currently showed most responses to tailored management in this simulation study. Tailored management calls for later planting during an El Niño, and earlier planting in a La Niña. When planting dates were tailored to ENSO phases, simulations showed at least $10 \%$ lower nitrogen leaching from rainfed production systems in about $70 \%$ of the years. Among ENSO phases, La Niña seasons were shown to have greater nitrogen leaching, with little response to management changes relative to El Niño seasons. Tailored management may be most advantageous in El Niño seasons as a result of higher yields and lower nitrogen leaching. Further research is needed before options derived from simulations and optimization can be recommended and adopted with confidence by growers and extension advisors.
\end{abstract}

KEY WORDS: ENSO $\cdot$ Management decisions $\cdot$ Peanut irrigation $\cdot$ Planting date $\cdot$ Nitrogen leaching Resale or republication not permitted without written consent of the publisher

\section{INTRODUCTION}

The El Niño-Southern Oscillation (ENSO), through its influence on the climate of Florida, exerts considerable influence on agricultural production. The Florida Department of Agriculture attributed about \$165 million of losses in economic activity to agriculture and forestry in Florida due to the 1997-1998 El Niño event. Adams et al. (1995) estimated the potential annual benefit of ENSO-based climate forecasts to agriculture in the Southeast USA at around \$100 million. ENSO phases have measurable effects on the yields of 7 of the 10 most important crops to the economy of the Southeast

*Corresponding author. E-mail: ssjagtap@mail.ifas.ufl.edu
(Hansen et al. 1998, 2001). El Niño was associated with decreased winter yields of tomato (18\% of the long-term average), bell pepper $(18 \%)$, corn $(10 \%)$, sweetcorn $(15 \%)$ and snap beans (12\%). El Niño events were associated with increased sugarcane yields following $\mathrm{La}$ Niña years, and increased yields of grapefruit (5\%) and tangerines $(13 \%)$ but decreased lime yields in the harvest following El Niño events. Furthermore, ENSO has a significant association with corn and tobacco yields, areas of soybean and cotton harvested, and total values of corn, soybean, peanut and tobacco in Alabama, Florida, Georgia and South Carolina. Hansen et al. (2001) showed that there is an almost \$500 million difference in the value of these 4 crops between neutral and cold or warm ENSO phases. 
Green et al. (1997) have shown that El Niño has little discernable influence on total summer precipitation in Florida. In the summer, climate impacts of El Niño events are more localized. With some exceptions, La Niña events show the reverse of the climate anomalies associated with El Niño events. Knowledge of ENSO events relative to crop growing season is important for understanding analyses of ENSO's influence on agriculture. Although the timing of ENSO events may vary among years, summer field crops (March-October) are most influenced by the preceding ENSO phase (Hansen et al. 2001). For southern Georgia, Hansen et al. (2001) attributed maize yield response to ENSO primarily to enhanced June precipitation in La Niña years, coinciding with tasseling, when maize is most susceptible to water stress.

This paper investigates possible management options for peanut Arachis hypogaea L. production in the Southeast, assuming prior knowledge of El Niño phases. In a series of state-wide meetings with peanut farmers and extension agents, Jagtap et al. (2001a) and Hildebrand et al. (2000) found that peanut farmers in Florida repeatedly requested information on the expected climate of the upcoming season to improve yields and irrigation management decisions. Water stress and planting dates were identified as the most important factors limiting peanut yield in the state. When irrigation is not an option, farmers hope to control the timing of the water deficit by selecting sowing dates that minimize water stress and its impact on yield. When irrigation was feasible, sowing times as well as timing and amount of irrigation were the most important factors to reduce costs.

Highly productive but relatively small farms and high levels of inputs dominate peanut production at these sites. Although peanut is not fertilized with nitrogen, it symbiotically fixes large quantities of nitrogen that are left behind in residues after harvest. When decomposed, these residues release nitrogen that may leach into the groundwater, creating adverse off-site effects. As there is substantial rainfall during and after harvesting peanuts in Florida and Georgia, there are concerns about the environmental and health impacts of nitrate from agricultural fields (Murphy et al. 2000).

Until now, little if any was known about how either planting date and irrigation practices based on ENSO may improve peanut yield in the southern US. Elsewhere, simulation studies have shown associations between El Niño phases and yields of peanuts in Australia (Meinke et al. 1996), corn in Zimbabwe (Phillips et al. 1999) and Argentina (Ferreyra et al. 2001), and a mix of crops in other locations (Messina et al. 1999, Jones et al. 2000, Hansen et al. 2001). Crop models were the preferred choice of analysis because of their ability to simulate yield response to alternate manage- ment conditions, such as planting date, row spacing, plant population, irrigation and cultivar choice, over many years of historical weather records (Meinke \& Hammer 1995, Boote et al. 1996, 1998).

No attempt has been made to assess the likely effects of El Niño phases and management on nutrient leaching. The objectives of this paper were to explore for 3 locations in Florida and 1 in Georgia (1) how choice of planting date and irrigation management options affected simulated peanut yields and yield variability and (2) how the tailored management practices (with respect to yield and yield variability) affected the simulated $\mathrm{N}$ leaching of rainfed and irrigated peanuts.

\section{MATERIAL AND METHODS}

\subsection{Study sites}

Three sites were selected in north Florida (Tallahassee $30.23^{\circ} \mathrm{N}, 84.22^{\circ} \mathrm{W}$; Milton $30.78^{\circ} \mathrm{N}, 87.01^{\circ} \mathrm{W}$; and Levy $29.42^{\circ} \mathrm{N}, 82.82^{\circ} \mathrm{W}$ ), and 1 in south Georgia (Tifton $31.5^{\circ} \mathrm{N}, 83.5^{\circ} \mathrm{W}$ ); the elevation of all 4 stations is close to sea level $(<100 \mathrm{~m})$. Peanut is one of the main crops grown in these areas (Fig. 1). Early planting begins in April and ends by May in Florida and June in Georgia (NASS 1997). Most farmers, however, plant during the optimum planting window of 15 April to 1 May in Florida and about 2 wk later in Georgia. Peanuts normally mature approximately 135 to $140 \mathrm{~d}$ after planting (Fig. 1). The same variety may take 15 to $30 \mathrm{~d}$ longer to mature when planted early or late in the season.

\subsection{Climate and ENSO phases}

Daily weather data for all sites from 1947-1990 were obtained from the National Climatic Data Center Summary of the Day database (EarthInfo 1996). Daily weather records for the most recent years in Tifton were obtained from the Georgia Automated Environmental Monitoring Network (Hoogenboom \& Gresham 1997). Florida weather data after 1990 are from the Florida Automated Weather Network (http://fawn.ifas.ufl.edu). The weather data from Tallahassee and Milton covered the period 1948-1998. The data series started a year earlier for Tifton (1947-1998) and somewhat later in Levy (1956-1998). Daily solar irradiance data were available only for Tifton and Tallahassee. For Milton and Levy, these data were estimated from daily air temperature, using RadEst v. 3.0, calibrated for nearby Tallahassee and Gainesville $\left(29.63^{\circ} \mathrm{N}, 82.37^{\circ} \mathrm{W}\right)$.

El Niño phases (El Niño, La Niña and Neutral) were categorized by the Japan Meteorological Agency 
(JMA 1991) definition based on 5 mo running means of spatially averaged sea-surface temperature (SST) anomalies in the region of the tropical Pacific Ocean between $4^{\circ} \mathrm{N}-4^{\circ} \mathrm{S}$ and $90-150^{\circ} \mathrm{W}$. A crop year (March-October) for our locations was classified as El Niño (La Niña) if the SST anomalies were $\geq 0.5^{\circ} \mathrm{C}$ $\left(\leq 0.5^{\circ} \mathrm{C}\right)$ for at least 6 consecutive months and if this 6 mo period started before October of the previous year (Meyers et al. 1999). Similarly, fallow period (November-February) is under the current year's ENSO phase. The period 1947-1998 included $12 \mathrm{El}$ Niño (1952, 1958, 1964, 1966, 1970, 1973, 1977, 1983, 1987, 1988, 1992 and 1998) and 11 La Niña events (1950, 1955, 1956, 1957, 1965, 1968, 1971, 1972, 1974, 1976 and 1989). The remaining 28 years were Neutral.

\subsection{Crop simulations}

Peanut simulations were performed using CROPGRO-Peanut (Hoogenboom et al. 1992, 1994, Boote \&
Tollenaar 1994, Boote et al. 1998, Jones et al. 1998), a dynamic process crop model that simulates crop carbon, soil water, and crop and soil nitrogen balances under different climate, soil, and management conditions. It includes light interception, leaf-level photosynthesis, soil $\mathrm{N}$ balance, $\mathrm{N}$ uptake, $\mathrm{N}_{2}$ fixation, soil water balance, evapotranspiration, respiration, leaf area growth, pod and seed addition, growth of component parts, root growth, senescence, N mobilization, carbohydrate dynamics, and crop development processes. CROPGRO-Peanut is available as part of the DSSAT v. 3.5 (Jones et al. 1998) software. The model has been coupled with a geographic information system for site-specific production recommendations.

CROPGRO-Peanut was calibrated with 7 on-station trials at Gainesville (Boote \& Jones 1988, Boote et al. 1988) and validated with 21 on-farm trials in Levy and Jackson counties in north Florida (Boote et al. 1989, Gilbert et al. 2001). Jackson county sites were inbetween Milton (180 km by road to east) and Tallahassee (100 km to northwest), and to $240 \mathrm{~km}$ south of Tifton

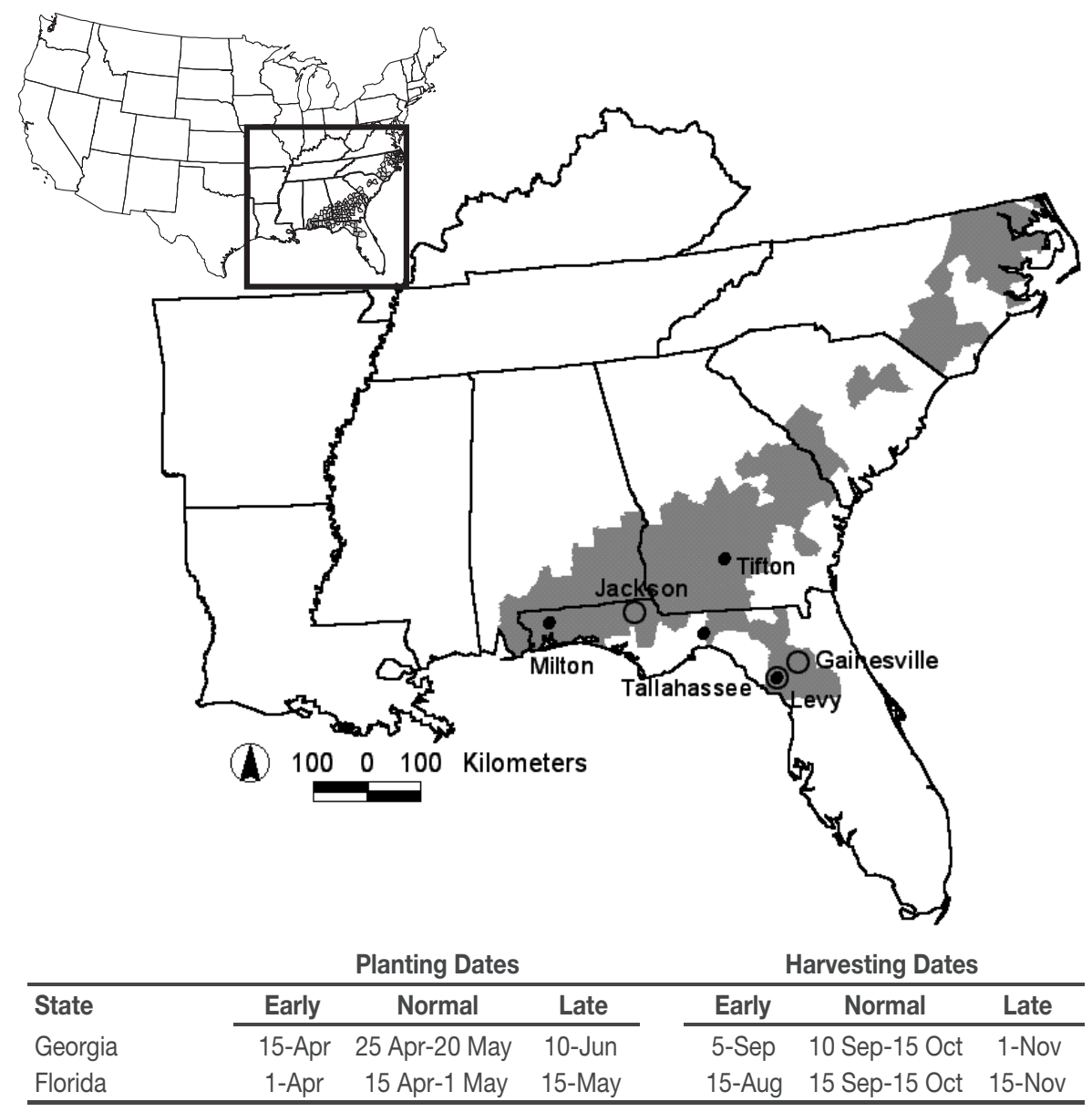

Fig. 1. Peanut production regions in the Southeastern USA and the sites used for calibration and validation (O) of the CROPGROPeanut model, and in this simulation $(\bullet)$ study. Usual ranges of peanut planting dates and harvesting dates are also shown 
(Fig. 1). When simulated yields were compared to measured yields at Gainesville, yield was underpredicted 3 times (range -20 to $-5 \%$ ) and overpredicted 4 out of the 7 times (range +1 to $+23 \%$ ) with an average absolute error of $13 \%$. In 3 on-farm evaluations in 1988, the model tended to over-predict yields on farms with disease and nematode problems on average by $+33 \%$. In 1989 the model errors were reduced to about $+10 \%$ (Boote et al. 1989). Gilbert et al. (2001) also validated the model on 15 farms in Levy and Jackson counties in north Florida. In the years and fields that had low disease pressure, the model simulations were $9 \%$ above observed yields. In fields that had high levels of disease problems, the model simulations were 24 to $44 \%$ above observed yields (Gilbert et al. 2001). In all these simulation trails, CROPGRO-Peanut did correctly predict relative yields decreases due to water stress. The model has also been compared across multiple sites spanning several climatic zones in India and was found to accurately predict soil water contents and yield across sowing dates and soils (Singh et al. 1994).

CROPGRO-Peanut appears to be useful as a predictor of optimal peanut yield under given cultivar, soil, weather and management variables (Boote et al. 1998). It does not explicitly simulate soil fertility or biotic stresses such as disease, insects or nematodes and may over-predict yield. An empirical soil fertility and soildisease correction factor is included as an input to bring average simulated yields for locations where climatic peanut yield potential is not attained due to biotic stresses closer to those observed yields. In experimental studies, Boote et al. (1997) have estimated this factor to be 0.92 for all Florida locations. Due to the higher incidence of soil-based pests and diseases in Tifton than in Florida, this factor is 0.77 for Tifton (Mavromatis et al. 2001). The soil fertility and soildisease factor reduces canopy photosynthesis by $8 \%$ in Florida and $23 \%$ in Georgia daily throughout the growing season, and therefore biomass growth rate. Even with the correction factor, CROPGRO-Peanut may still over-predict observed on-farm yield under excessive disease and pest pressure. In a regional study Jagtap \& Jones (2001) computed yield correction factors ranging from 0.40 to 0.50 to reduce bias between simulated and observed soybean yields over more than $75 \%$ of Georgia. The yield correction factors indicate the extent of yield gap between actual and achievable yields currently present due to uncontrolled stresses.

The simulation study used Florunner, which is the most widely ( $73 \%$ of total US production; Raymer et al. $1989,1997)$ grown cultivar in the region due to its combination of commercially desirable characteristics and the ability to yield relatively well under most conditions. In this simulation study, Florunner was sown in
$0.61 \mathrm{~m}$ rows at a density of 16 plants $\mathrm{m}^{-2}$. For each location, representative soil characteristics and management practices were obtained from published studies and researchers familiar with each region. The soil type and family in Tifton were described by Mavromatis et al. (2001). The VEMAP soil database was used for the locations in Florida. VEMAP is a $0.5^{\circ}$ (approximately $50 \mathrm{~km}$ ) 'gridded' database that is based on the $10 \mathrm{~km}$ soil database developed by Kern $(1994,1995)$ using the USDA Soil Conservation Service national soil database (NATSCO).

Planting date was the main experimental treatment that was tested for differences in yields between ENSO phases. Other management options, such as changing planting density, were not considered in our study, since peanut growers do not consider them as options. Since peanut is a crop that is characterized by its lack of photoperiod sensitivity and high drought tolerance (Boote et al. 1998), a rather wide planting window was used at 1 wk intervals (from March 15 to June 28) in order to explore the modeled rainfed and irrigated yield crop response to sowing date.

The first year of simulation was initialized with soil water at $75 \%$ of water-holding capacity, in line with a relatively wet January to March period (Jagtap \& Jones 2001). Subsequent simulations were conducted as a continuous sequence of crop and bare fallow with carryover of soil water, residues and nitrogen. Two irrigation options were explored. CROPGRO-Peanut was set to automatically apply 1 inch $(0.025 \mathrm{~m})$ of water when needed (i.e. whenever the available soil water in the top $0.3 \mathrm{~m}$ root zone was depleted by $25 \%$ or more) from first pod to harvest maturity (pod filling irrigation), a common current practice (K. J. Boote pers. comm.). Water stress is a unitless value between 0 and 1 computed daily as a ratio of water deficit (i.e. the difference between demand for water and supply of water) to water demand.

The weight of 100 seeds was used as a seed quality indicator (Pedelini 1988), and $\mathrm{N}$ leaching during the growing season (March-October) and the following bare fallow period (November-February) was used as an index of environmental quality. The effects of tillage, pests and diseases, water logging, lodging and harvest losses were not simulated. Simulated yield and weight of seeds are reported as dry weights.

\subsection{Selecting the optimum planting date}

We assumed that there are wide ranges of plausible planting dates that potentially could maximize peanut yields and minimize year-to-year variability. The optimization procedure identified a planting date that resulted in the highest yield followed by the lowest 
coefficient of variation (CV) for all years during each of the 3 ENSO phases. When 2 planting dates gave the same yield, the one with the lowest $C V$ was selected as the optimum planting date. Both these criteria must be satisfied to avoid situations where one planting gives maximum yield but another planting date gives the minimum CV.

\subsection{Analyses}

An independent $t$-test was used to test whether the ENSO phases affected simulated yields for each location when the assumptions of normality and equality of variance held. If tests of either assumption failed, the nonparametric Mann-Whitney (Mann \& Whitney 1947) rank sum test was used instead. To test the hypothesis of equal interannual variability between ENSO phases, Levene's (1960) method was applied when the samples were normally distributed. However, when a Kolmogorov-Smirnov single-sample test (Conover 1999) indicated significant non-normality, the Brown \& Forsythe (1974) modification of Levene's test was applied.

The effects of peanut management (planting date and irrigation) tailored to ENSO phases on simulated yield (mean and CV), weight per 100 seeds, and $\mathrm{N}$ leaching were compared with those of current management (rain- fed and irrigated), and they were reported as deviations on a percent basis. The same statistical tests described before were used to test the statistical significance of percent changes.

\section{RESULTS AND DISCUSSION}

\subsection{Response of rainfed simulated yield and weight per seed to ENSO phases}

Simulated mean yield (CV) varied from $3262 \mathrm{~kg} \mathrm{ha}^{-1}$ $(24 \%)$ at Tifton to a high of $5405 \mathrm{~kg} \mathrm{ha}^{-1}(13 \%)$ at Levy. Yields (CV) were higher (lower) during La Niña events and lower (higher) during El Niño years compared to all year means in all locations (Table 1). Additionally, for rainfed planting dates yields were higher during $\mathrm{La}$ Niña events than for Neutral and El Niño years at all locations. Our results agree with the findings of Hansen et al. (2001), who also identified this tendency in statewide mean peanut production in Florida using historical records. The largest and smallest mean yield differences were found between La Niña and Neutral events (from $0.3 \%$ in Levy to $18.5 \%$ in Tifton). Only Tifton showed higher peanut yield during El Niño relative to Neutral years. No significant differences in mean simulated peanut yields were found among ENSO phases for the current planting dates in the 3

Table 1. Simulated mean rainfed yield and coefficient of variation (CV), weight per 100 seeds (WSD) and N leaching (NL) for each ENSO phase for the current planting dates at the 4 locations. NL was estimated on a seasonal basis (growing season [MarchOctober] + subsequent fallow period [November-February]). Means and CV of El Niño, La Niña and Neutral phases with common superscripted letters within each location differ significantly at the 0.05 probability level

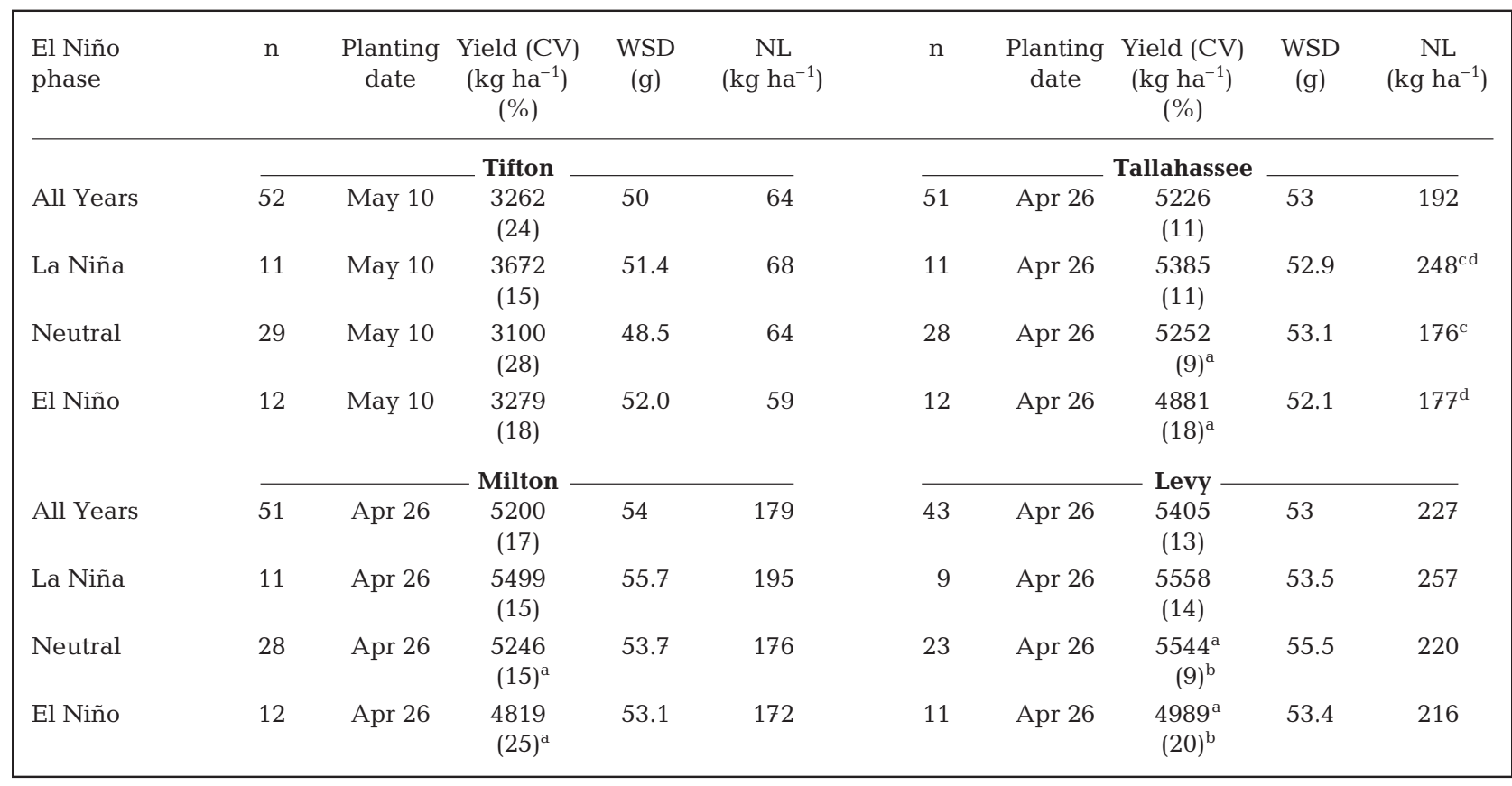



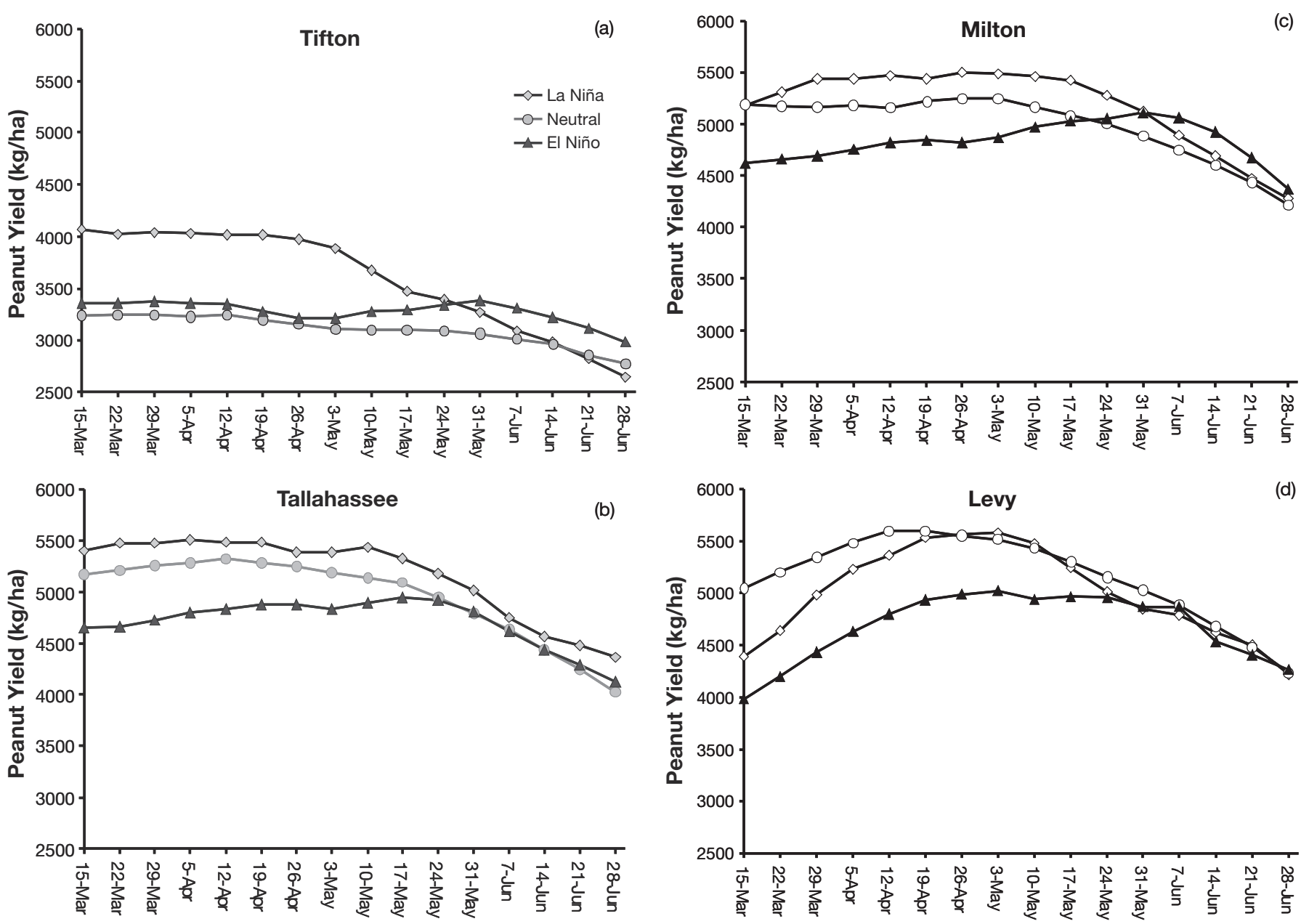

Fig. 2. Simulated mean rainfed yield by ENSO phases across plantings in (a) Tifton, (b) Tallahassee, (c) Milton, and (d) Levy

locations (Tifton, Tallahassee and Milton). In Levy, however, the mean yield for El Niño events was significantly lower $(10 \%)$ than the respective mean for Neutral years. The year-to-year variability for El Niño years was also found to be significantly higher $(\mathrm{p}<0.05)$ than for Neutral years in all sites but Tifton.

Simulated peanut yields for early plantings during La Niña years in all locations but Levy were higher than for the other 2 phases (Fig. 2a-c). In Levy, the mean simulated yield for La Niña increased as planting was delayed (Fig. 2d). The yield declined sharply for May or later plantings. The Florida locations, in contrast with Tifton, showed large yield differences between Neutral and El Niño years. These simulated yield responses to planting dates are consistent with current planting practices in these regions. Planting is usually completed by June 10 in Georgia and by May 15 in Florida (Fig. 1; NASS 1997).

Higher yields contributed to higher seed weights in Florida compared to Georgia. Keeping in line with higher yields, rainfall and sandy Florida soils, N leaching was 3 to 4 times more than in Georgia (Table 1). Annual $\mathrm{N}$ leaching for planting after La Niña events was $15-40 \%$ higher than for plantings following El Niño events.

The CV for El Niño years in Tallahassee and Milton was substantially higher than for the other 2 phases for plantings early in the season, reaching its minimum values for May 17 and early June planting dates, respectively (Fig. 3b,c). The CV for La Niña and Neutral events, on the other hand, did not show much variation with planting date. CV of yield in Levy decreased sharply with planting date until the end of April, when the CV of Neutral events achieved its lowest values (Fig. 3d). The CV in Tifton, in contrast to the other locations, was less responsive to changes in planting date (Fig. 3a).

The yield gain (loss) by tailoring planting of rainfed peanut by ENSO phase was not significantly different at the $95 \%$ confidence level. However, the gains in 

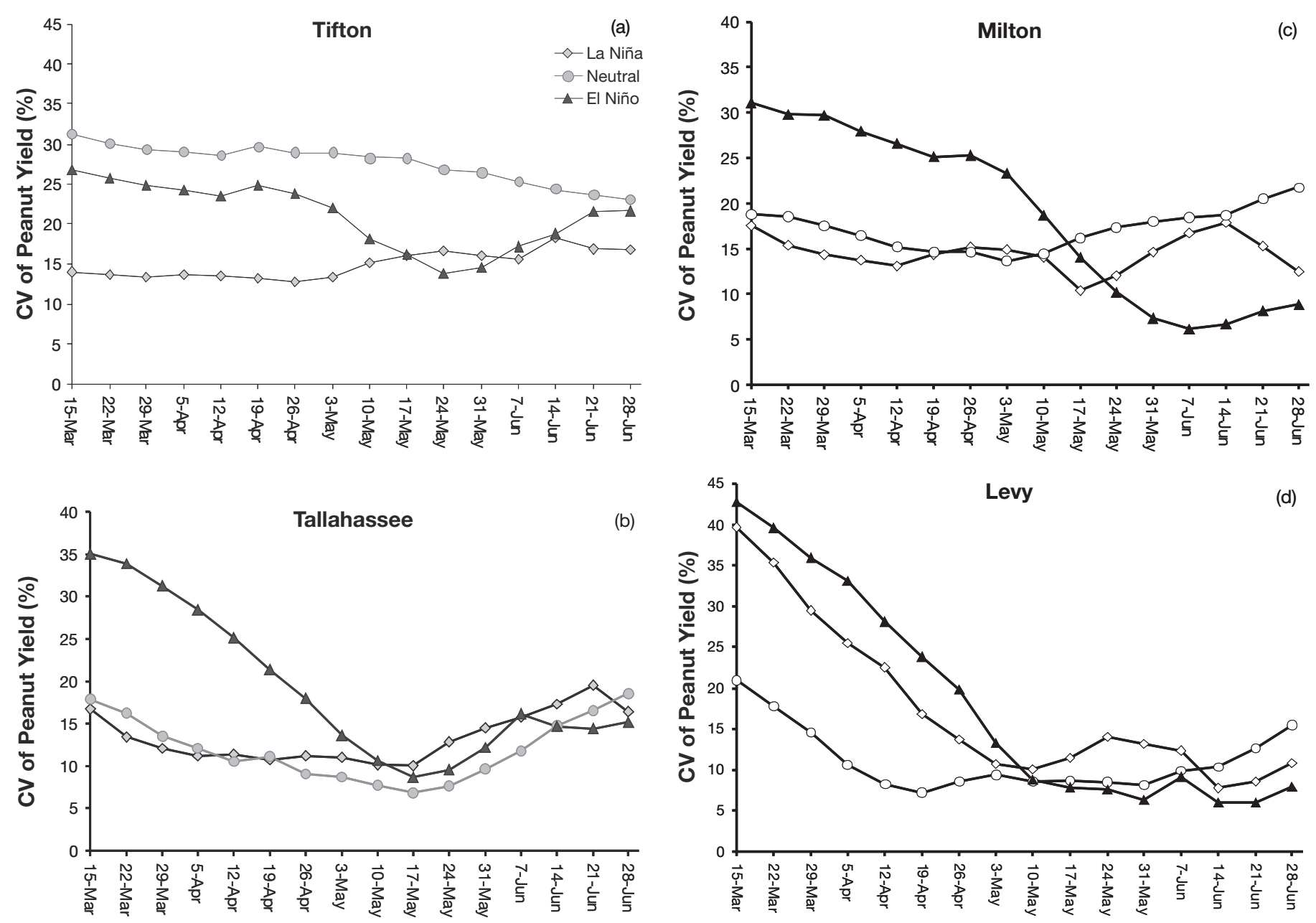

Fig. 3. Simulated coefficient of variation (CV) of rainfed yields by ENSO phases across plantings in (a) Tifton, (b) Tallahassee, (c) Milton, and (d) Levy

yield, seed weight and $\mathrm{N}$ leaching were generally higher than optimized values for all years (Table 2). The mean yield in Tifton and Milton increased by more than $3 \%$ above current planting date yields for all ENSO phases. For all the other sites and phases, the benefits of shifting the timing of planting would be more related to a reduction in the $\mathrm{CV}$ rather than an increase in the mean yield. That was the case particularly for the Florida locations during El Niño. Weight per seed marginally but consistently increased in most cases, and $\mathrm{N}$ leaching was reduced for La Niña and El Niño seasons (Table 2). These benefits in El Niño years were the results of postponing current planting dates by $21 \mathrm{~d}$ (except at Levy). Our simulated results are consistent with the response of some peanut farmers in northern Florida and south Georgia in 1998 (Letson et al. 2001). The farmers, being aware that 1998 was an El Niño year, delayed planting. Those who did, in anticipation of heat and drought stress, avoided the cata- strophic losses that were later experienced by those who planted at the usual time.

To gain a better understanding of the role of climate variability on peanut growth and yield differences between El Niño and La Niña phases, temperature and rainfall for each location for the planting date of April 26 were analyzed. The higher simulated yields achieved with La Niña events were associated with lower mean air temperatures, lower year-to-year variability in rainfall amounts, higher solar irradiance (except at Tifton), and lower simulated water stress during the pod-filling period relative to El Niño events (Table 3). In CRPGRO-Peanut, the seed growth rate function for peanuts has its optimum at $24^{\circ} \mathrm{C}$. At higher than optimum temperatures the crop starts to exhibit poorer than optimum fruit formation and partitioning (Boote et al. 1998). Furthermore, the higher year-toyear variability, particularly of rainfall, for El Niño years compared with that of La Niña seasons resulted 
Table 2. Optimum planting dates for all years and by ENSO phases and \% changes in yield and CV, weight per 100 seeds (WSD) and $\mathrm{N}$ leaching $(\mathrm{NL})$ at the 4 locations. NL was estimated on a seasonal basis (growing season [March-October] + subsequent fallow period [November-February])

\begin{tabular}{|c|c|c|c|c|c|c|c|c|}
\hline $\begin{array}{l}\text { El Niño } \\
\text { phase }\end{array}$ & $\begin{array}{l}\text { Planting } \\
\text { date }\end{array}$ & $\begin{array}{c}\text { Yield (CV) } \\
(\%)\end{array}$ & $\begin{array}{l}\text { WSD } \\
(\%)\end{array}$ & $\begin{array}{l}\text { NL } \\
(\%)\end{array}$ & $\begin{array}{l}\text { Planting } \\
\text { date }\end{array}$ & $\begin{array}{c}\text { Yield (CV) } \\
(\%)\end{array}$ & $\begin{array}{l}\text { WSD } \\
(\%)\end{array}$ & $\begin{array}{l}\text { NL } \\
(\%)\end{array}$ \\
\hline & \multicolumn{4}{|c|}{ Tifton } & \multicolumn{4}{|c|}{ Tallahassee } \\
\hline All years & Apr 12 & $\begin{array}{c}+5.2 \\
(+1.4)\end{array}$ & +0 & +0 & Apr 19 & $\begin{array}{c}+0.0 \\
(-1)\end{array}$ & +0 & +0 \\
\hline La Niña & Apr 26 & $\begin{array}{l}+8.1 \\
(-12)\end{array}$ & +3.1 & -1.3 & Apr 19 & $\begin{array}{r}+1.8 \\
(0)\end{array}$ & +1.5 & -0.4 \\
\hline Neutral & Apr 12 & $\begin{array}{l}+4.7 \\
(+5)\end{array}$ & +0.2 & +8.1 & Apr 26 & $\begin{array}{l}0.0 \\
(-2)\end{array}$ & 0.0 & 0.0 \\
\hline \multirow[t]{2}{*}{ El Niño } & May 31 & $\begin{array}{l}+3.1 \\
(-10)\end{array}$ & +0.6 & -11 & May 17 & $\begin{array}{l}+1.3 \\
(-2)\end{array}$ & +1.2 & -3.1 \\
\hline & \multicolumn{4}{|c|}{ Milton } & \multicolumn{4}{|c|}{ Levy } \\
\hline All years & May 3 & $\begin{array}{l}+0 \\
(-2)\end{array}$ & +0 & +0 & May 3 & $\begin{array}{l}+0 \\
(-2)\end{array}$ & +0 & +0 \\
\hline La Niña & May 17 & $\begin{array}{c}-1.4 \\
(-7)\end{array}$ & 0.0 & -3.6 & May 3 & $\begin{array}{l}+0.4 \\
(-2)\end{array}$ & +2.2 & -3.4 \\
\hline Neutral & May 3 & $\begin{array}{r}-0.1 \\
(-3)\end{array}$ & +0.2 & -2.7 & Apr 19 & $\begin{array}{l}+1.0 \\
(-6)\end{array}$ & +0.2 & -2.2 \\
\hline El Niño & May 17 & $\begin{array}{r}+4.4 \\
(-3)\end{array}$ & +3.0 & -9.2 & May 3 & $\begin{array}{r}+0.5 \\
(0)\end{array}$ & -0.7 & +2.6 \\
\hline
\end{tabular}

Table 3. Simulated average yield, temperature ( $\left.T_{\text {mean }}\right)$, solar irradiance (Rad), rain and water stress on growth (WS, a ratio) from first seed to harvest maturity for each ENSO phase for the planting date of April 26 at the 4 locations. Statistics include the standard deviation (SD) of simulated variables in parentheses

\begin{tabular}{|c|c|c|c|c|c|c|c|c|c|c|}
\hline $\begin{array}{l}\text { El Niño } \\
\text { phase }\end{array}$ & $\begin{array}{c}\text { Yield } \\
\left(\mathrm{kg} \mathrm{ha}^{-1}\right)\end{array}$ & $\begin{array}{l}T_{\text {mean }} \\
\left({ }^{\circ} \mathrm{C}\right)\end{array}$ & $\begin{array}{c}\operatorname{Rad} \\
\left(\mathrm{MJ} \mathrm{m}^{-2} \mathrm{~d}^{-1}\right)\end{array}$ & $\begin{array}{l}\text { Rain } \\
(\mathrm{mm})\end{array}$ & $\begin{array}{c}\text { WS } \\
\left(\mathrm{kg} \mathrm{ha}^{-1}\right)\end{array}$ & $\begin{array}{l}\text { Yield } \\
\left({ }^{\circ} \mathrm{C}\right)\end{array}$ & $\begin{array}{c}T_{\text {mean }} \\
\left(\mathrm{MJ} \mathrm{m}^{-2} \mathrm{~d}^{-1}\right)\end{array}$ & $\begin{array}{l}\text { Rad } \\
(\mathrm{mm})\end{array}$ & Rain & WS \\
\hline & & & Tifton & & & & & \multirow{2}{*}{$\begin{array}{c}\text { Tallahassee } \\
20.5 \\
(0.6)\end{array}$} & & \\
\hline La Niña & $\begin{array}{l}3971 \\
(508)\end{array}$ & $\begin{array}{l}26.5 \\
(0.4)\end{array}$ & $\begin{array}{l}20.8 \\
(0.4)\end{array}$ & $\begin{array}{l}335 \\
(72)\end{array}$ & $\begin{array}{c}0.136 \\
(0.091)\end{array}$ & $\begin{array}{l}5385 \\
(603)\end{array}$ & $\begin{array}{l}26.9 \\
(0.4)\end{array}$ & & $\begin{array}{c}483 \\
(115)\end{array}$ & $\begin{array}{c}0.046 \\
(0.072)\end{array}$ \\
\hline Neutral & $\begin{array}{l}3157 \\
(909)\end{array}$ & $\begin{array}{l}26.9 \\
(0.7)\end{array}$ & $\begin{array}{l}21.3 \\
(0.6)\end{array}$ & $\begin{array}{c}292 \\
(100)\end{array}$ & $\begin{array}{c}0.245 \\
(0.179)\end{array}$ & $\begin{array}{l}5252 \\
(477)\end{array}$ & $\begin{array}{l}27.2 \\
(0.6)\end{array}$ & $\begin{array}{l}20.4 \\
(1.0)\end{array}$ & $\begin{array}{c}481 \\
(150)\end{array}$ & $\begin{array}{c}0.040 \\
(0.077)\end{array}$ \\
\hline El Niño & $\begin{array}{l}3213 \\
(763)\end{array}$ & $\begin{array}{l}26.9 \\
(0.7)\end{array}$ & $\begin{array}{l}21.4 \\
(0.7)\end{array}$ & $\begin{array}{c}350 \\
(124)\end{array}$ & $\begin{array}{c}0.191 \\
(0.112)\end{array}$ & $\begin{array}{l}4881 \\
(879)\end{array}$ & $\begin{array}{l}27.3 \\
(0.5)\end{array}$ & $\begin{array}{l}20.4 \\
(1.0)\end{array}$ & $\begin{array}{c}492 \\
(185)\end{array}$ & $\begin{array}{c}0.064 \\
(0.093)\end{array}$ \\
\hline La Niña & $\begin{array}{l}5499 \\
(833)\end{array}$ & $\begin{array}{l}26.6 \\
(0.4)\end{array}$ & $\begin{array}{c}\text { Milton } \\
21.5 \\
(0.5)\end{array}$ & $\begin{array}{c}421 \\
(125)\end{array}$ & $\begin{array}{c}0.088 \\
(0.080)\end{array}$ & $\begin{array}{l}5558 \\
(762)\end{array}$ & $\begin{array}{l}26.7 \\
(0.3)\end{array}$ & $\begin{array}{c}\text { Levy } \\
19.5 \\
(0.7)\end{array}$ & $\begin{array}{c}605 \\
(158)\end{array}$ & $\begin{array}{c}0.036 \\
(0.076)\end{array}$ \\
\hline Neutral & $\begin{array}{l}5246 \\
(769)\end{array}$ & $\begin{array}{l}27.0 \\
(0.6)\end{array}$ & $\begin{array}{l}21.0 \\
(1.0)\end{array}$ & $\begin{array}{c}484 \\
(173)\end{array}$ & $\begin{array}{c}0.065 \\
(0.097)\end{array}$ & $\begin{array}{l}5544 \\
(479)\end{array}$ & $\begin{array}{l}26.9 \\
(0.6)\end{array}$ & $\begin{array}{l}19.5 \\
(0.8)\end{array}$ & $\begin{array}{l}596 \\
(96)\end{array}$ & $\begin{array}{c}0.010 \\
(0.022)\end{array}$ \\
\hline El Niño & $\begin{array}{c}4819 \\
(1218)\end{array}$ & $\begin{array}{l}27.0 \\
(0.6)\end{array}$ & $\begin{array}{l}21.2 \\
(0.8)\end{array}$ & $\begin{array}{c}449 \\
(148)\end{array}$ & $\begin{array}{c}0.099 \\
(0.144)\end{array}$ & $\begin{array}{l}4989 \\
(989)\end{array}$ & $\begin{array}{l}27.3 \\
(0.5)\end{array}$ & $\begin{array}{l}19.2 \\
(0.5)\end{array}$ & $\begin{array}{c}662 \\
(234)\end{array}$ & $\begin{array}{c}0.040 \\
(0.073)\end{array}$ \\
\hline
\end{tabular}

in higher variability of water stress on crop growth and finally in higher yield variability.

The simulated yields for each of the El Niño and La Niña crop seasons in Tifton are illustrated as circles (the area of each circle is proportional to the yield) versus mean air temperature and precipitation during the pod filling stage in Fig. 4. The mean temperature and rainfall totals for La Niña and El Niño seasons are presented as horizontal and vertical lines. The higher yield variability in El Niño years (Fig. 4b) compared to La Niña years (Fig. 4a) is evident, as is the higher range of precipitation and temperature in El Niño years. The most productive La Niña seasons were those with above average precipitation (Fig. 4a). In contrast, the 3 lowest yield seasons (1983, 1987 and 1998) (Fig. 4b) were associated with above-average temperatures and below-average precipitation amounts, a combination that resulted in higher simu- 

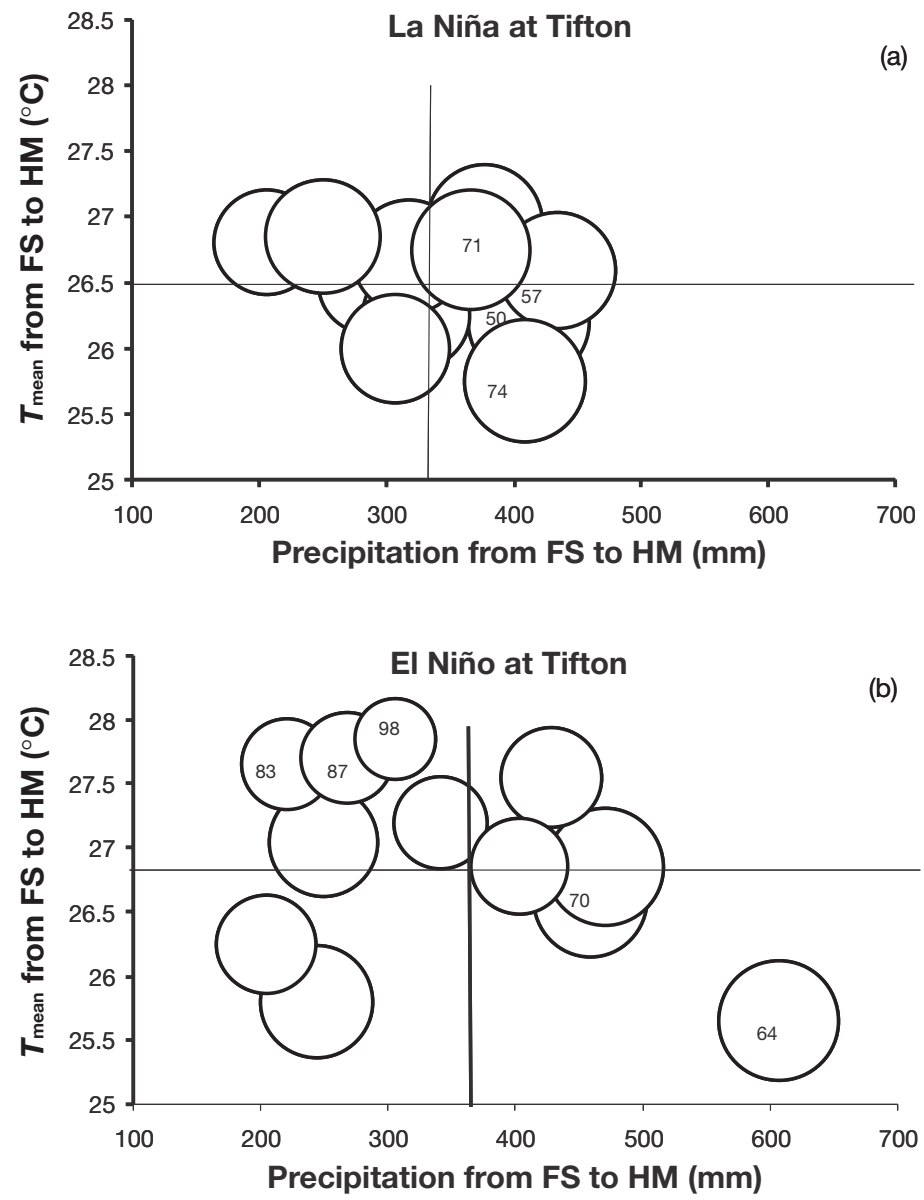

Fig. 4. Simulated yield (represented by circles, where the greater the area the higher the yield) vs mean air temperature $\left(T_{\text {mean }}\right)$ and precipitation from first seed (FS) to harvest maturity (HM) for each of the (a) La Niña and (b) El Niño years in Tifton. The mean temperature and rainfall totals for La Niña and El Niño events are presented as horizontal and vertical lines

lated water stress compared with the mean values for El Niño years (Table 3). The 2 El Niño years of 1970 and 1964 that received above-average rainfall and below-average temperatures resulted in the highest simulated yields.

\subsection{Response to simulated irrigation during pod filling}

Not surprisingly, irrigation from first pod to harvest maturity combined with tailoring planting dates increased simulated yields by 3 to $10 \%$ with the exception of Levy (Table 4). We attributed these yield responses to reduced (increased) mean air temperatures and increased (decreased) solar irradiance in La Niña (El Niño) during the pod-filling period. The yield benefits from tailoring planting date to an ENSO phase and applying irrigation during pod fill relative to the planting date optimized over all years were significant and higher for Tifton than for the Florida sites (Table 4). At the Florida locations, yield benefits were only significant during Neutral phases, but caused increased simulated $\mathrm{N}$ leaching. The enhanced simulated yields were achieved with small, but not statistically significant in most cases, increases in irrigation water. Tifton required 3 to 4 more irrigation applications than the Florida locations. Yield benefits were achieved with earlier plantings, when the mean air temperature was closer to the optimum for peanuts. The weight per seed consistently increased as well, suggesting improved grain quality, and $\mathrm{N}$ leaching increased. Overall, irrigation consistently improved yields and grain quality, and lowered CV and $\mathrm{N}$ leaching at Tifton during La Niña's (Table 4).

\subsection{Response of simulated $\mathbf{N}$ leaching to ENSO phases}

We explored the influence of all combinations of subsequent phases (i.e. during the growing season [March-October] and during the subsequent fallow period [November-February]) on simulated $\mathrm{N}$ leaching. A crop year (March-October) for our locations was classified based on the ENSO phase that started in October of the previous year, while a fallow period (November-February) was classified on the ENSO phase of the current year. In Tifton, the higher $\mathrm{N}$ leaching occurred when the crop season was followed by an El Niño phase. These fallow periods received higher total rainfall amounts than Neutral and La Niña phases $\left(3.67 \mathrm{~mm} \mathrm{~d}^{-1}\right.$ vs 3.16 and 2.89 , respectively). $\mathrm{N}$ leaching tended to be lowest when the subsequent fallow periods were La Niña, which were the driest $\left(2.89 \mathrm{~mm} \mathrm{~d}^{-1}\right)$.

$\mathrm{N}$ leaching was substantially higher in Florida due to higher total precipitation, particularly during the growing season (Table 1). La Niña or Neutral crop seasons preceding El Niño bare fallow periods showed the highest $\mathrm{N}$ leaching. This $\mathrm{N}$ response was also attributed to the higher rainfall totals observed during El Niño bare fallow periods compared to Neutral and La Niña. Very high $N$ leaching was also found during Neutral fallow periods following El Niño growing seasons. The combinations of Neutral growing seasons preceding La Niña fallows resulted in the lowest $\mathrm{N}$ leaching due to the very low observed precipitation amounts and the efficient crop nitrogen uptake (as evidenced by the higher yields compared 
Table 4. Optimum planting dates by ENSO phases for irrigated peanuts and changes in irrigated modeled yield, irrigation days, weight per 100 seeds (WSD) and N leaching (NL). Statistics include the coefficient of variation (CV) of the simulated yield and the number of irrigations (IR) for current planting dates. NL was estimated on seasonal basis (growing season [March-October] + subsequent fallow period [November-February]). Changes in ${ }^{*}$ means and ${ }^{* *} \mathrm{CV}$ of ENSO phases that differ significantly at the 0.05 probability level are indicated

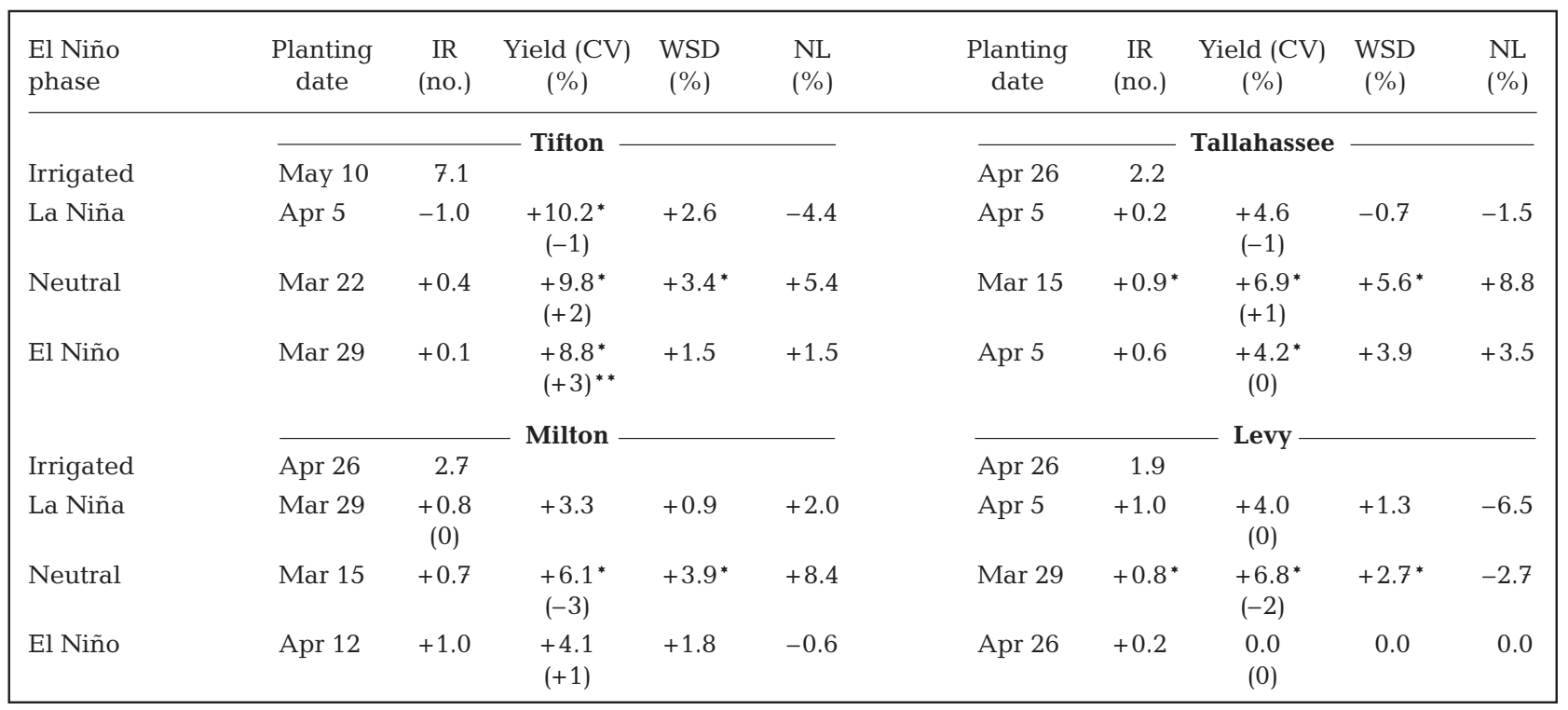

with the other 2 phases; Table 1) during the crop season. $\mathrm{N}$ leaching was similar across different ENSO phases when deficit irrigations were applied during the growing season.

Tailoring planting date (with respect to mean yield and yield $\mathrm{CV}$ ) of rainfed crops decreased total $\mathrm{N}$ leaching (crop season + subsequent fallow) for El Niño crop seasons in Tifton by $11 \%$ no matter what phase followed the crop season (Table 2). The opposite responses of $\mathrm{N}$ leaching were found with Neutral growing seasons. In Florida locations, $\mathrm{N}$ leaching decreased consistently at Tallahassee and Milton. Benefits were higher for Milton than for Levy and Tallahassee. Across all sites and years, tailoring planting of rainfed management decreased $\mathrm{N}$ leaching in $70 \%$ of the years, while in the remaining $30 \%$ of the years it remained unchanged or increased.

Small increases in total $\mathrm{N}$ leaching (Table 4) in most of the cases was found after tailoring planting date of irrigated peanuts to Neutral and El Niño phases in Georgia. The opposite was found for La Niña growing seasons, with a decrease of about $4 \%$. N leaching increased in the majority of cases in Tallahassee and Milton and decreased in Levy. These changes were mainly attributed to the more drastic shifting in planting dates for irrigated than for rainfed crops (Tables 3 \& 4). Overall, tailoring planting of irrigated peanuts for maximum yields decreased (increased) $\mathrm{N}$ leaching in $41 \%(59 \%)$ of the years.

\section{CONCLUSIONS}

It is possible to utilize an ENSO phases to improve peanut production in Georgia and Florida. ENSO does have an impact on peanut productivity, variability among years, seed quality and susceptibility for nitrogen leaching (Table 5). Although results varied from state to state, simulation analyses suggest that farmers can improve their yields (1-8\%), lower year-to-year variability (2-12\%), and nitrogen leaching (1-11\%) in years characterized as El Niño and La Niña by tailoring planting dates (Table 5) at 3 out of the 4 locations where the study was conducted. Although initial analysis (Table 1) showed that ENSO had significant ( $p=0.05$ ) impact on yield and CV at Levy, in the final analysis, it showed the smallest response to tailored planting dates. Sites for which there is little discernable influence from ENSO showed the greatest response to tailored planting dates. La Niña generally has a very positive effect across the sites. El Niño combined with late planting resulted in lower nitrogen leaching. According to simulation, the optimum planting window for rainfed production was $21 \mathrm{~d}$ later in El Niño years with no consistent pattern (14 d early to 21 d late) among locations in La Niña years (Table 5). Tailoring planting dates and applying irrigation showed that simulated $\mathrm{N}$ leaching would increase in more than half of the years, with the exception of Tifton (Table 5). 
Table 5. Summary of potential benefits of tailored planting dates according to the phases of ENSO on peanut yield, yield variability $(\mathrm{CV})$, nitrogen leaching, and number of irrigations averaged over La Niña and El Niño years at the study sites. A positive planting date change refers to delays in planting, whereas a negative planting date means an early planting. A positive number refers to an increase in value, whereas a negative one means a reduction in value. nc: change was less than $1 \%$

\begin{tabular}{|c|c|c|c|c|c|}
\hline ENSO phase & Site & $\begin{array}{c}\text { Planting } \\
\text { date change }\end{array}$ & $\begin{array}{l}\text { Yield } \\
\% \text { change }\end{array}$ & $\begin{array}{c}\mathrm{CV} \\
\text { \% change }\end{array}$ & $\begin{array}{l}\text { Leaching } \\
\text { \% change }\end{array}$ \\
\hline \multicolumn{6}{|l|}{ Rainfed production } \\
\hline \multirow[t]{4}{*}{ La Niña } & Tifton & -14 & +8 & -12 & -1 \\
\hline & Tallahassee & -7 & +1 & -2 & nc \\
\hline & Milton & +21 & -1 & -7 & -4 \\
\hline & Levy & +7 & $\mathrm{nc}$ & -2 & -3 \\
\hline \multirow[t]{3}{*}{ El Niño } & Tifton & +21 & +3 & -10 & -11 \\
\hline & Tallahassee & +21 & +1 & -2 & -3 \\
\hline & Milton & +21 & +4 & -3 & -9 \\
\hline $\begin{array}{l}\text { Irrigated production } \\
\text { ENSO phase }\end{array}$ & Site & $\begin{array}{c}\text { Planting } \\
\text { date change }\end{array}$ & $\begin{array}{l}\text { Yield } \\
\% \text { change }\end{array}$ & $\begin{array}{l}\text { Irrigations } \\
\text { change }\end{array}$ & $\begin{array}{l}\text { Leaching } \\
\% \text { change }\end{array}$ \\
\hline La Niña & Tifton & -35 & +10 & -1 & -4 \\
\hline
\end{tabular}

The results of this study may have been different if we had tailored planting date and irrigation management to minimize for $\mathrm{N}$ leaching, seed quality or even income return rather than for production risk and seed yield. An economic evaluation of the management decisions would not be realistic, since the indirect effects of climate on insect pests and diseases were not modeled. This would become an important factor because fungicide applications, the measures producers take against diseases, are some of the major production costs of peanuts especially in the Southeast (Pedelini 1988).

Further research is needed before options derived from simulation and optimization can be recommended and adopted with confidence by growers and extension advisors. Farmers also might benefit from adjusting land allocation among crops based on ENSO phase (Jones et al. 2000). A joint research and extension initiative has been launched (Jagtap et al. 2001b) to disseminate climate information to growers in Florida. This initiative includes components for generation, communication and use of climate information as well as an implementation and evaluation.

Acknowledgements. Florida Agricultural Experiment Station, Journal Series No. R-08269.

\section{LITERATURE CITED}

Adams RM, Bryant KJ, McCarl BA, Legler DM, O'Brien J, Solow A, Weiher R (1995) The value of improved longrange weather information. Contemp Econ Policy 13: 10-19

Boote KJ, Jones JW (1988) Application of, and limitations to, crop growth simulation model to fit crops and cropping systems to semi-arid environments. In: Bidinger FR, Johansen C (eds) Drought research priorities for the dryland tropics. ICRISAT, A.P. 502324, Hyderabad, p 63-75

Boote KJ, Tollenaar M (1994) Modeling genetic yield potential. In: Boote KJ, Bennett JM, Sinclair TR, Paulsen GM (eds) Physiology and determination of crop yield. ASACSSA-SSSA, Madison, WI, p 533-565

Boote KJ, Jones JW, Hoogenboom G, Wilkerson GG, Jagtap SS (1988) PEANUTGRO V1.1 Peanut crop growth simulation model: user's guide. Florida Agricultural Experiment Station Journal No. 8420, Agricultural Engineering Department and Agronomy Department, University of Florida, Gainesville, and IBSNAT Project, Department of Agronomy and Soil Science, University of Hawaii, Honolulu

Boote KJ, Bennet JM, Jones JW, Jowers HE (1989) On-farm testing of peanut and soybean models in north Florida. Paper No. 89-4040. American Society Agricultural Engineers, St. Joseph, MI

Boote KJ, Jones JW, Pickering NB (1996) Potential uses and limitations of crop models. Agron J 88:704-716

Boote KJ, Jones JW, Hoogenboom G, Wilkerson GG (1997) Evaluation of the CROPGRO-Soybean model over a wide range of experiments. In: Kropff MJ, Teng PS, Agarwal PK, Bouma J, Bouman BAM, Jones JW, van Laar HH (eds) Applications of systems: approaches at the field level. Kluwer Academic Publishers, p 113-133

Boote KJ, Jones JW, Hoogenboom G (1998) Simulation of crop growth: CROPGRO Model. In: Peart RM, Curry RB (eds) Agricultural systems modeling and simulation. Marcel Dekker, New York, p 651-692

Brown MB, Forsythe AB (1974) Robust tests for the equality of variances. J Am Stat Assoc 69:264-267

Conover WJ (1999) Practical nonparametric statistics, 3rd edn. John Wiley \& Sons, New York

EarthInfo (1996) Database guide for EarthInfo CD NCDC Summary of the Day. EarthInfo, Boulder, CO

Ferreyra RA, Podesta GP, Messina CD, Letson D, Dardanelli J, Guevara E, Meira S (2001) A linked-modeling framework to estimate maize production risk associated with 
ENSO-related climate variability in Argentina. Agric For Meteorol 107:177-192

Gilbert R, Boote KJ, Bennett JM (2001) On-farm testing of the PNUTGRO crop growth model in Florida. Florida Agricultural Experiment Station Journal Series No. R-08279. University of Florida, Gainesville

Green PM, Legler DM, Miranda V, O'Brien JJ (1997) The North American climate patterns associated with El NiñoSouthern Oscillation. Report 97-1, Center for OceanAtmospheric Prediction Studies, Tallahassee, FL

Hansen JW, Hodges A, Jones JW (1998) ENSO influences on agriculture in the southeastern United States. J Clim 11: 404-411

Hansen JW, Jones JW, Irmak A, Royce F (2001) El Niño-Southern Oscillation impacts on crop production in the Southeast United States. In: Hatfield JL, Volenec JJ, Dick WA, Kral DM (eds) Impacts of El Niño and climate variability on agriculture. ASA Special Publication no. 63. Madison, WI

Hildebrand P, Caudle A, Cabrera V, Downs M and 5 others (2000) Potential use of long range climate forecasts by agricultural extension agents in Florida. Florida Consortium Technical Report FC-UF-2000-001, University of Florida, Gainesville

Hoogenboom G, Gresham DD (1997) Automated weather station network. In: Hatcher KJ (ed) Proc 1997 Georgia Water Resources Conference. Institute of Ecology, The University of Georgia, Athens, p 483-486

Hoogenboom G, Jones JW, Boote KJ (1992) Modeling growth, development, and yield of grain legumes using SOYGRO, PNUTGRO, and BEANGRO: a review. Trans Am Soc Agric Eng 35:2043-2056

Hoogenboom G, Jones JW, Wilkens PW, Batchelor WD and 9 others (1994) Crop models. In: Tsuji GY, Uehara G, Balas S (eds) DSSAT v3. University of Hawaii, Honolulu, p 95-244

Jagtap SS, Jones JW (2001) Scaling-up crop models for regional yield and production estimation: a case-study of soybean production in the state of Georgia, USA. In: Kobayashi K (ed) Proc Crop Monitoring and Prediction at Regional Scales, Tsukuba, Japan, February 19-22, 2001. p 171-186

Jagtap SS, Jones JW, Zazueta F, Jackson J, Beck H, Hildebrand P (2001a) Bridging the gap between climate prediction and its application in Florida agriculture. Technical Report FC-UF-2001-1. Dept of Agriculture and Biological Engineering, University of Florida, Gainesville

Jagtap SS, Jones JW, Hildebrand P, O'Brien JJ, Podestá G, Letson D, Zazueta F, Zierden D (2001b) Responding to stakeholders demand for climate information: from research to practical applications in Florida. Technical Report FC-UF-2001-4. Dept of Agriculture and Biological Engineering, University of Florida, Gainesville

JMA (Japan Meteorological Agency) (1991) Climate charts of sea-surface temperature of the western North Pacific and the global ocean. Marine Department, Japan Meteorological Agency, Tokyo

Jones JW, Tsuji GY, Hoogenboom G, Hunt LA and 5 others (1998) Decision support system for agrotechnology transfer: DSSAT v3. In: Tsuji GY, Hoogenboom G, Thornton PK (eds) Understanding options for agricultural production. Kluwer Academic Publishers, Dordrecht, p 157-177

Jones JW, Hansen JW, Royce FS, Messina CD (2000) Potential benefits of climate forecasting to agriculture. Agric Ecosyst Environ 82:169-184

Editorial responsibility: Robert Davis,

Charlottesville, Virginia, USA
Kern SJ (1994) Spatial pattern of soil organic carbon in the contiguous United States. Soil Sci Soc Am J 58:439-455

Kern SJ (1995) Geographic pattern of soil water holding capacity in the contiguous United States. Soil Sci Soc Am J 59:1126-1133

Letson D, Hansen J, Hildebrand P, Jones JW, O'Brien J, Podesta G, Royce F, Zierden D (2001) Florida's agriculture and climatic variability: reducing vulnerability. Florida Consortium Technical Report FC-UF-2001-001, University of Florida, Gainesville

Levene H (1960) Robust tests for equality of variance. In: Olkin I (ed) Contributions to probability and statistics. Stanford University Press, Palo Alto, CA

Mann HB, Whitney DR (1947) On a test of whether one or two random variables is stochastically larger than the other. Ann Math Stat 18:50-60

Mavromatis T, Boote KJ, Jones JW, Irmak A, Shinde D, Hoogenboom G (2001) Developing genetic coefficients for crop simulation models using data from crop performance trials. Crop Sci 41:40-51

Meinke H, Hammer GL (1995) Climatic risk to peanut production: a simulation study for northern Australia. Aust J Exp Agric 35:777-780

Meinke H, Stone RC, Hammer GL (1996) SOI phases and climatic risk to peanut production: a case study for northern Australia. Int J Climatol 16:783-789

Messina CD, Hansen JW, Hall AJ (1999) Land allocation conditioned on ENSO phases in the Pampas of Argentina. Agric Syst 60:197-212

Meyers SD, O'Brien J, Thelin E (1999) Reconstruction of monthly SST in the Tropical Pacific ocean during 1868-1993 using adaptive climate basis functions. Mon Weather Rev 127:1599-1611

Murphy DV, Macdonald AJ, Stockdale EA, Goulding KWT and 6 others (2000) Soluble organic nitrogen in agricultural soils. Biol Fertil Soils 30:374-387

NASS (1997) Usual planting and harvesting dates for the US field crops. Agricultural Handbook No. 628. National Agricultural Statistics Service, Washington, DC

Pedelini R (1988) Effect of harvest date on yield, grade, and seed quality of 'Southern Runner' peanut. MS thesis, The University of Florida, Gainesville

Phillips JG, Cane MA, Rosenzweig C (1998) ENSO, seasonal rainfall patterns and simulated maize yield variability in Zimbabwe. Agric For Meteorol 90:39-50

Phillips JG, Rajagopalan B, Cane MA, Rosenzweig C (1999) The role of ENSO in determining climate and maize yield variability in the US cornbelt. Int J Climatol 19:877-888

Raymer PL, Day JL, Fisher CD, Heyerdahl RH (1989) 1988 field crops performance tests: soybeans, peanuts, cotton, tobacco, sorghum, summer annual forages, and sunflowers. Research Report No. 568. University of Georgia, Athens

Raymer PL, Day JL, Coy AE, Baker SH, Branch WD, LaHue SH (1997) 1996 field crops performance tests: soybean, peanut, cotton, tobacco, sorghum, grain millet and summer annual forages. Research Report No. 644. University of Georgia, Athens

Singh P, Boote KJ, Rao AY, Iruthayaraj MR, Sheikh AM, Hundal SS, Narang RS, Singh P (1994) Evaluation of the groundnut model PNUTGRO for crop response to water availability, sowing dates, and seasons. Field Crops Res 39:147-162

Submitted: July 9, 2001; Accepted: April 2, 2002

Proofs received from author(s): August 22, 2002 